\title{
The Capacity of a Ramp of the Pražský okruh x K Barrandovu Grade Separated Junction
}

\author{
L. Bartoš* \\ EDIP s.r.o., Mariánské Lázně, Západočeský kraj, Czech Republic, \\ *Corresponding author: bartos@edip.cz
}

J. Martolos

EDIP s.r.o., Plzeň, Plzeňský kraj, Czech Republic

V. Rozsypal

EDIP s.r.o., Liberec, Liberecký kraj, Czech Republic

J. Kašpar

HaskoningDHV CZ, Praha, Czech Republic

DOI: 10.2478/v10158-012-0035-y

\begin{abstract}
The aim of the article is to describe the method of experimental assessment of a grade-separated junction arm for ultimate traffic volume (capacity). The results of the assessment are compared with values stated in the current Czech Technical Standard CSN 73 6102, in the German guideline HBS, and in the Highway Capacity Manual (USA).
\end{abstract}

KEY WORDS: Traffic engineering, flyover, road capacity, traffic volume, traffic survey velocity.

\section{INTRODUCTION}

Grade-separated junctions are the ultimate capacity solution for an intersection layout. In view of the increasing rate of motorization, grade-separated junctions will form an ever-growing treatment of road junctions in the future, in spite of being the most expensive solution. Great attention should be paid to their capacity and efficiency. The capacity issue was the topic of the research project "Updating of models for grade-separated junctions capacity calculation" funded by the Czech Ministry of Transport within the National Research Program. The project has been carried out by the EDIP Ltd. and the DHV CR companies with the planned completion in 2010. The output of the project is TP 236 Assessment of capacity grade separated junctions (Rozsypal, 2011). A research project supported by the Technology Agency of the Czech Republic is currently being conducted whose aim is to unify and update the methodology for calculating the capacity of roads and a comprehensive methodology.

Four main elements influencing a grade-separated junction capacity were subsequently analyzed during the project, namely the beginning and end of the taper, the slip road ramp and the weaving distance. The aim of the article is to describe the traffic survey which has been carried out on a grade-separated junction ramp and to analyze data obtained and determine the ultimate limiting ramp capacity value. This value has been subsequently 
compared with theoretical values of ultimate capacities mentioned in relevant technical standards and guidelines.

\section{TRAFFIC SURVEY}



Figure 1: Queue of slowly moving vehicles on city circle in Prague (road R1) in the direction from Pilsen (Plzeň) at the place of the beginning of the ramp (the Pražský okruh $x$ K Barrandovu x Pod Lochkovem grade-separated junction).

The Pražský okruh x K Barrandovu x Pod Lochkovem grade-separated junction in Prague was chosen for the traffic survey implementation due to the criteria which clearly showed that this junction is reaching its ultimate capacity during peak hours (at the approach from Pilsen an almost $2 \mathrm{~km}$ long queue of slowly moving vehicles can be observed very often). Based on the site survey it was found that the limiting element of the junction is the capacity of the one-lane ramp in the direction from Pilsen to Barrandov. The layout of the trumpet junction mentioned is shown in Figure 2. The width of the relevant traffic lane is not constant - it varies from $4.75 \mathrm{~m}$ to $5.00 \mathrm{~m}$ in relation to the widening in the curve. The ramp is going uphill in the above-mentioned direction.

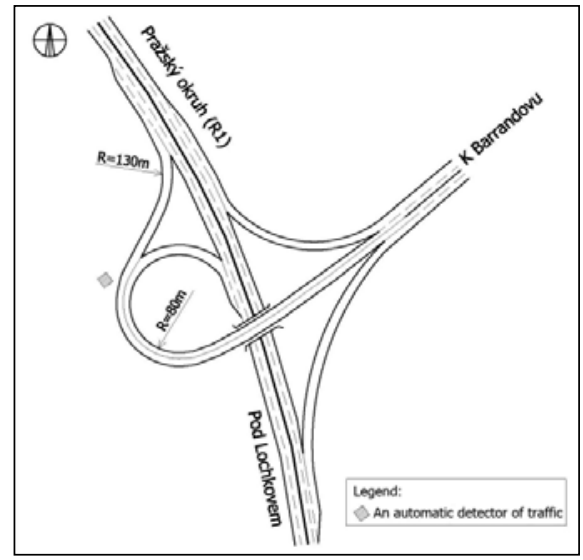

Figure 2: Layout of the grade-separated junction Pražský okruh x K Barrandovu x Pod Lochkovem.

An automatic detector was used to collect the traffic data in a one week period ( $25^{\text {th }}$ March $1^{\text {st }}$ April 2008) in the location of the ramp exit (see Figure 2 - gray rhomb). The detector was able to register time periods when vehicles (differentiated by their lengths) passed the 
detector, as well as the speed of each vehicle. In order to verify the results of the survey and for observation of the traffic behavior, an 80 minute video recording has been recorded during the afternoon peak.

\section{TRAFFIC VOLUMES}

The maximum volume of 22,114 vehicles per day as recorded on Friday, March $28^{\text {th }}, 2008$ indicates the high level of the one-lane above-mentioned ramp usage.

Daily variations of traffic volumes during the one week period are shown in Figure 3. A steep increase in traffic volume was observed in the morning peak (6 AM - 7 AM) when the volume reached values round 1,300 vehicles per day. Such high volumes persisted until $6 \mathrm{PM}$ thus indicating capacity exhaustion. The traffic volume declined during the evening and later in the night when heavy goods vehicles begin to dominate in the traffic flow.

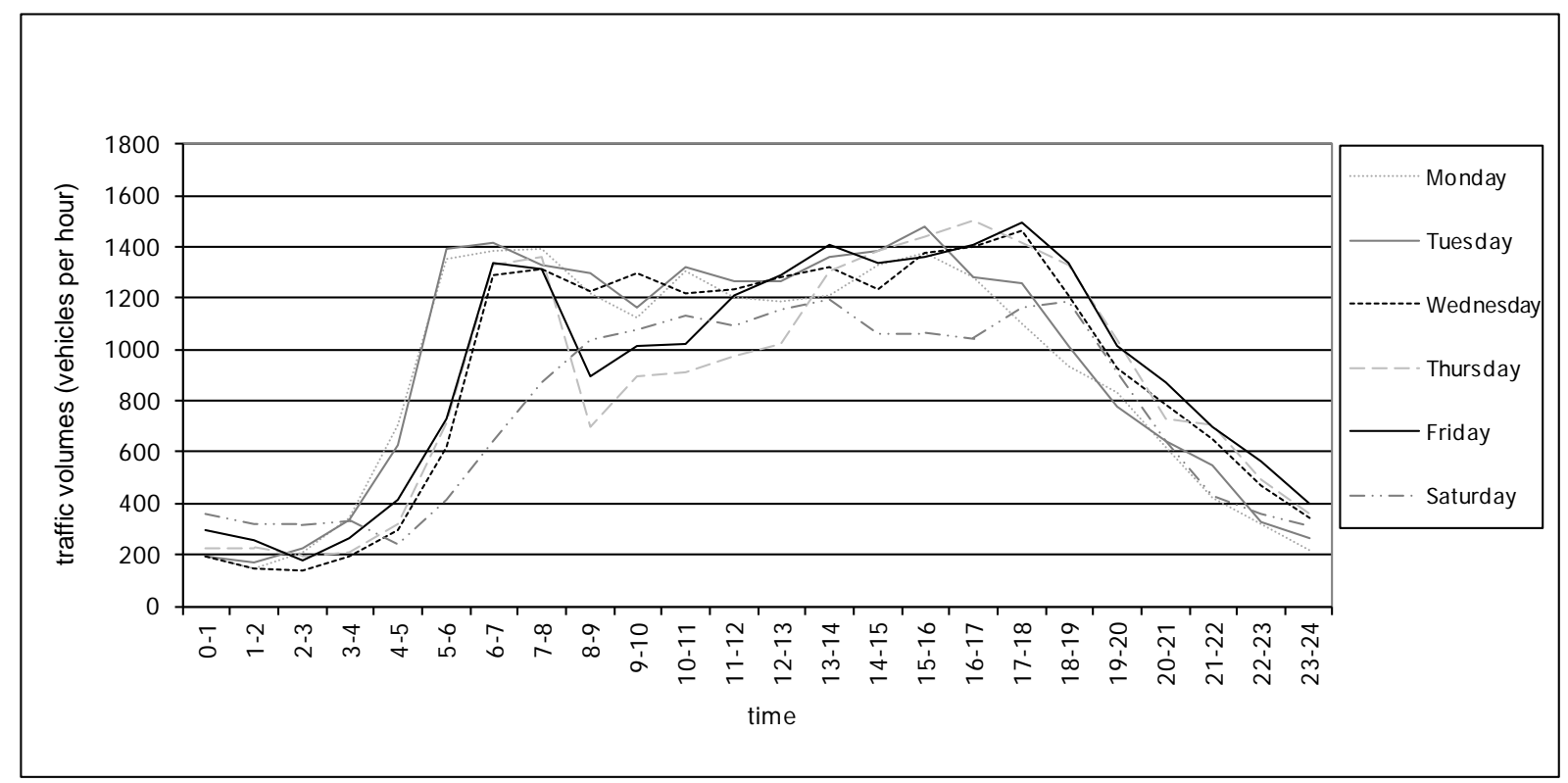

Figure 3: Daily variation of traffic volume on the afore-mentioned one-lane ramp.

Note: Omitted Sunday values were caused by a technical defect of the detector. A traffic abnormality in volumes can be seen during morning hours on Thursday and Friday, but this anomaly has not been further investigated.

Peak hour traffic volume was found on Thursday between 4 PM and 5 PM when a value of 1,503 vehicles per hour was reached. It corresponds to $7.2 \%$ of the whole day's traffic volume. During the peak hour the traffic flow consisted of $79.5 \%$ of passenger cars, $6.3 \%$ of heavy goods vehicles, $13.3 \%$ of long heavy goods vehicles and $0.4 \%$ of buses.

\section{SPEED}

The average profile speed of the traffic flow was $43 \mathrm{~km} / \mathrm{h}$ at the ramp exit. The highest speed of $94 \mathrm{~km} / \mathrm{h}$ was measured at 10:20 PM on Saturday and due to the small diameter of the curve the passengers of that car must have experienced a very emotional event. 
Frequency speed curves in an average working day (Tuesday) are shown in Figure 4 (for passenger cars) and in Figure 5 (for long heavy goods vehicles). The theoretical Gauss distribution is schematically illustrated in both graphs. The Gauss distribution was defined only from measurements carried out in the period outside of the ramp capacity depletion. Two obvious humps indicate that the speed is slowing down to $30 \mathrm{~km} / \mathrm{h}$ when the capacity was depleted, while outside this period the average speed is just below $50 \mathrm{~km} / \mathrm{h}$.

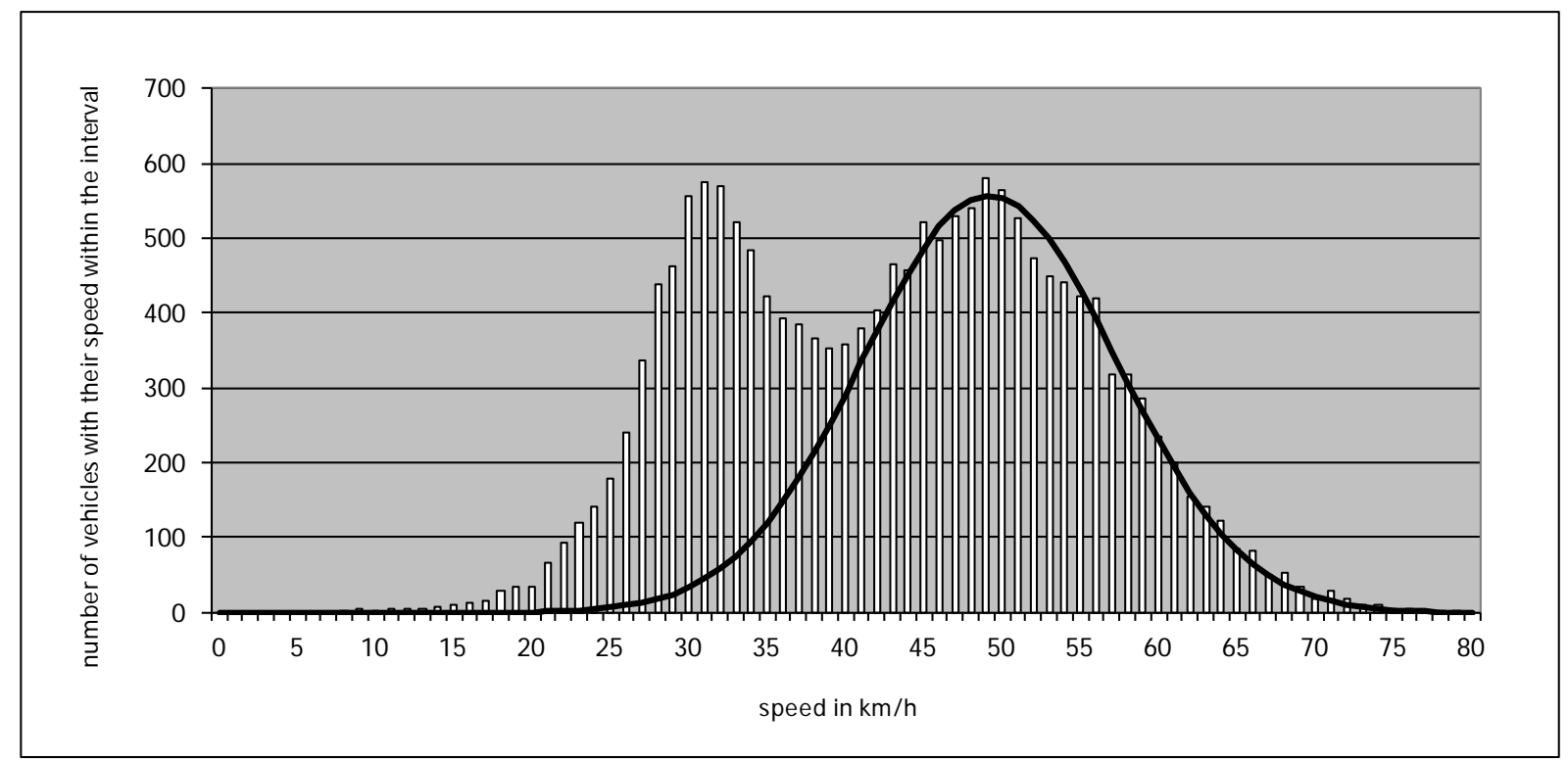

Figure 4: Histogram of speeds at the ramp exit on an average working day (Tuesday) passenger cars.

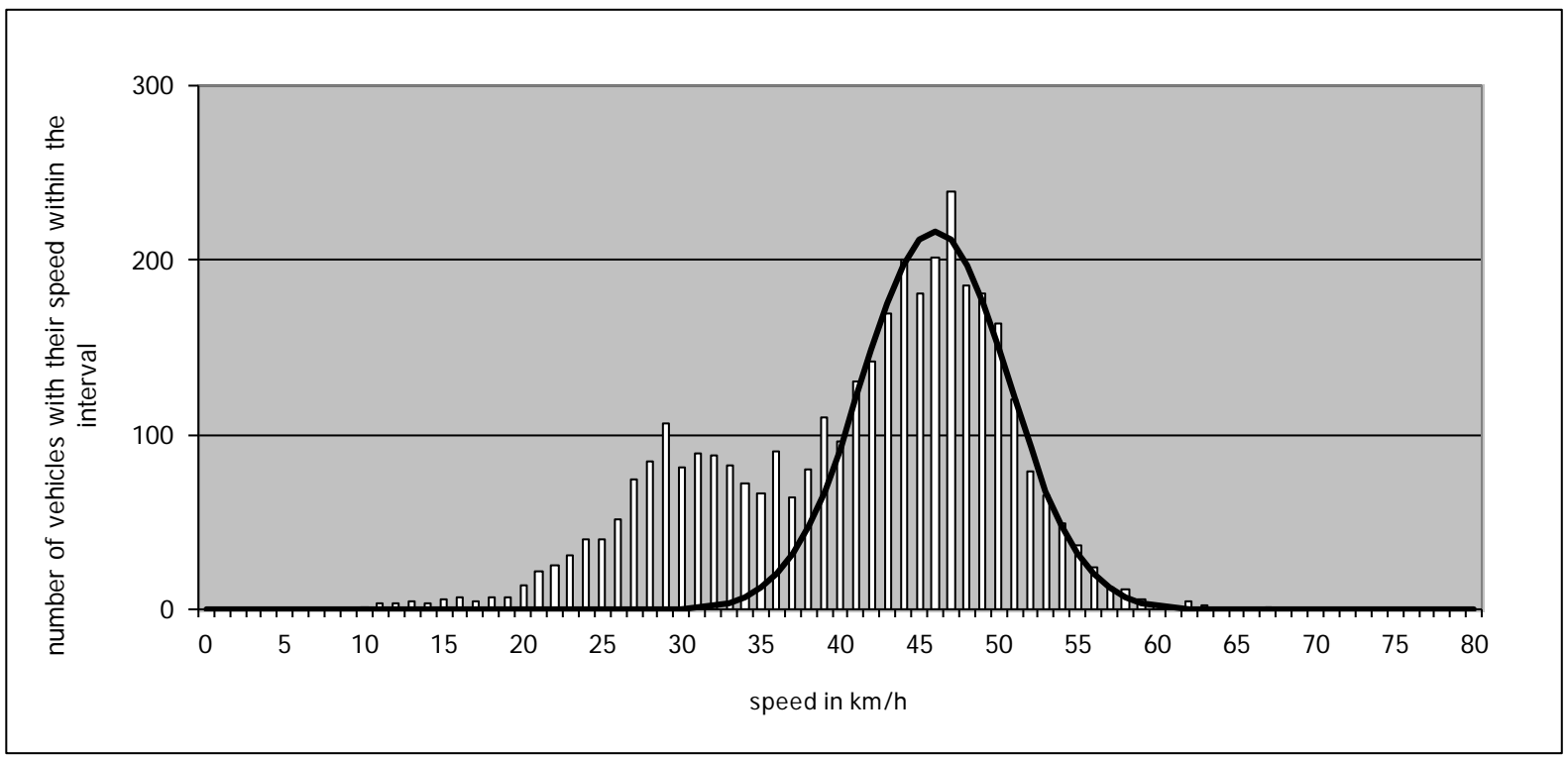

Figure 5: Histogram of speeds on the ramp exit on an average working day (Tuesday) - long heavy goods vehicles.

The value of average speed varies during the day. Comparison of these variations with daily variations of traffic volumes in an average working day (Tuesday) is shown in Figure 6. 


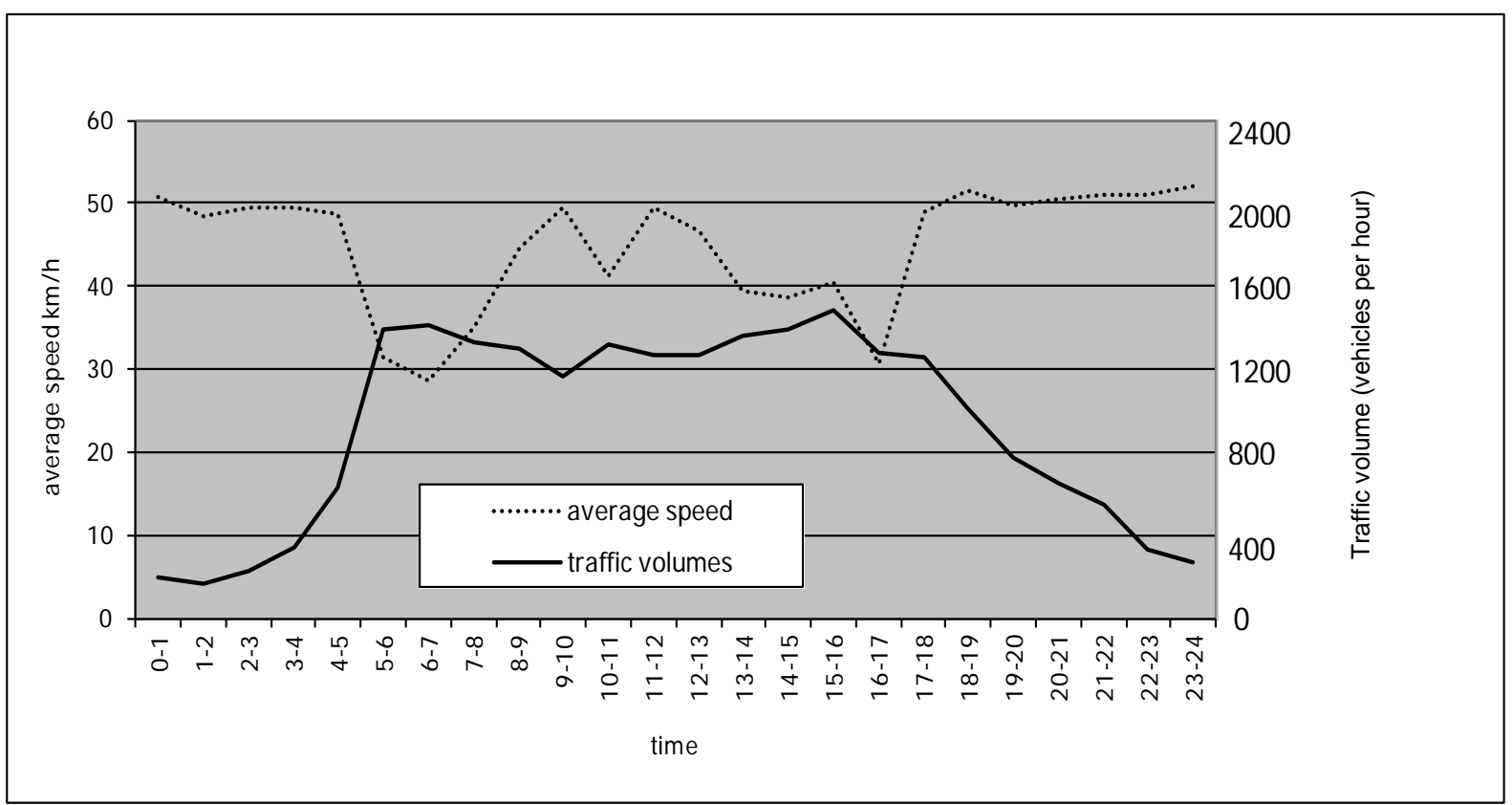

Figure 6: Comparison of average speed of the traffic flow at the ramp exit and the traffic volumes on an average working day (Tuesday).

\section{ULTIMATE TRAFFIC VOLUME (CAPACITY)}

Figure 7 demonstrates the level of ultimate traffic volumes (= capacity) of the ramp. Mutual dependence of the speed and the traffic volume is shown in the graph for each one-hour interval during the survey. The different colors show different shares of slow vehicles in an one-hour interval.

A particular dependence of the traffic flow speed on traffic volume, respectively on the level of load of the ramp, is evident. This dependence can be observed from a certain level of the traffic volume. Parameters of the traffic flow then contribute to a lower quality level because vehicles are influencing each other. Therefore, when assessing the capacity of a grade-separated junction ramp, it is essential to seek the value of traffic volume that the ramp can take without a radical decrease in the quality of traffic.

The ultimate level of the ramp traffic volume has been stated by measuring the value of 1,503 vehicles per hour with an average speed of $38 \mathrm{~km} / \mathrm{h}$. Based on the results shown in the graph in Figure 7, it can be seen that an increase in traffic volume above a value of approximately 1,200 vehicles per hour has a reciprocal effect on vehicles in the traffic flow and thus contributes to a slowing of the traffic. 


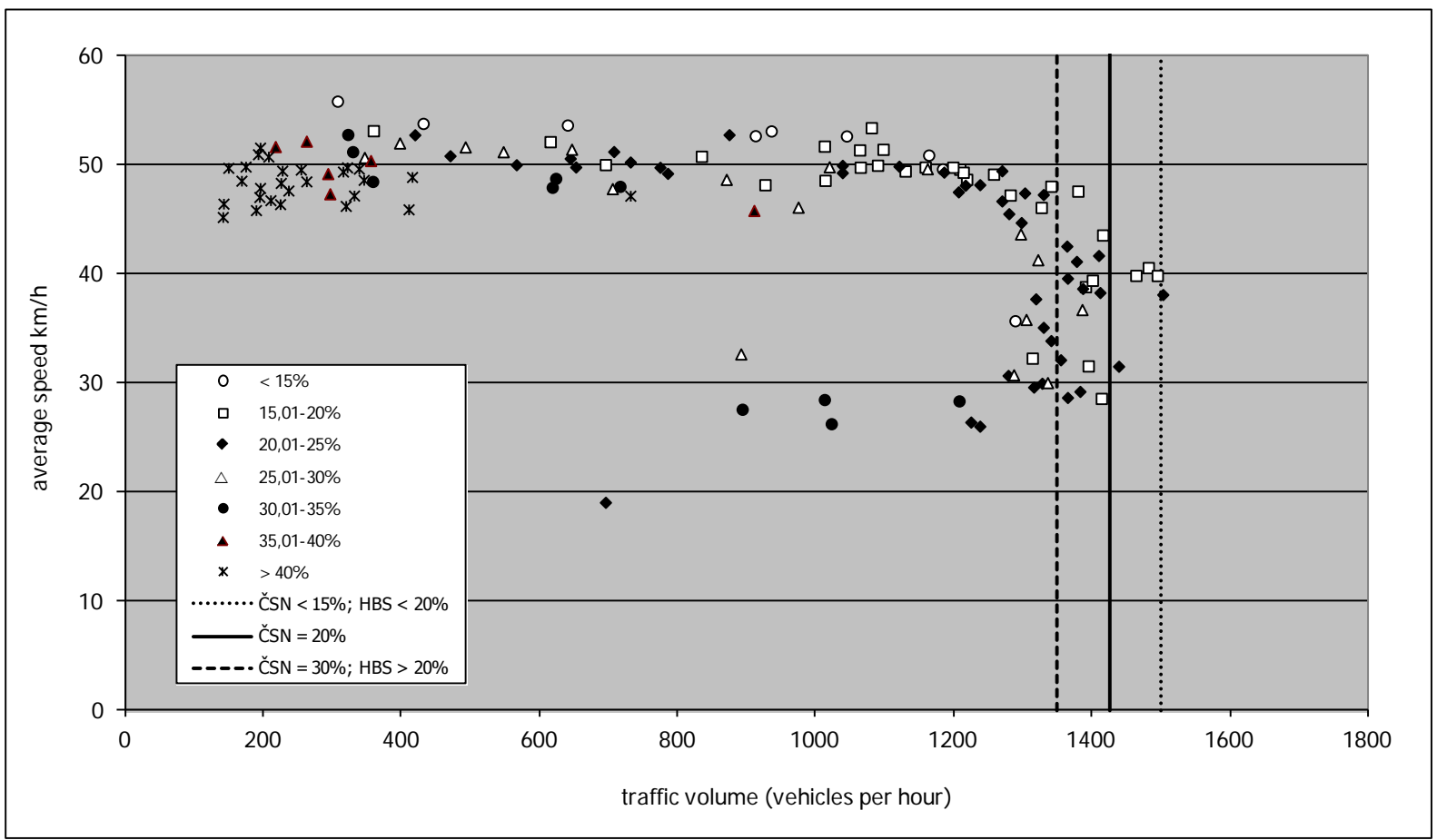

Figure 7: Dependence of speed and traffic volume on the ramp exit (all one-hour measurements within a one week period).

\section{COMPARISON OF MAXIMUM MEASURED TRAFFIC VOLUME WITH VALUES CALCULATED ACCORDING TO RELEVANT FOREIGN METHODS}

The above mentioned results were compared with the values of theoretical capacity for ramps of similar layout, which are stated in selected methodologies and guidelines - Czech technical standard (ČSN 73 6102, 2007), German guidelines (HBS, 2001) and the US guidelines (HCM, 2000). The results are shown in Table 1.

Table 1: Comparison of measured values of ultimate capacity with theoretical capacity values according to relevant methodologies.

\begin{tabular}{|l|c|c|c|c|c|}
\hline & $\begin{array}{c}\text { Traffic } \\
\text { survey }\end{array}$ & $\begin{array}{c}\check{C} \text { CSN } \\
736102\end{array}$ & HBS 2001 & HCM 2000 & TP 236 \\
\hline Capacity of the ramp & $1503 \mathrm{v} / \mathrm{h}$ & $1421 \mathrm{v} / \mathrm{h}$ & $1350 \mathrm{v} / \mathrm{h}$ & - & \\
\hline $\begin{array}{l}\text { Capacity of the ramp } \\
\text { (according to HCM) }\end{array}$ & $\begin{array}{l}1657 \\
\text { pce/h }\end{array}$ & - & - & $\begin{array}{l}1900 \\
\text { pce } / \mathrm{h}\end{array}$ & $\begin{array}{l}1800 \\
\text { pce/h }\end{array}$ \\
\hline
\end{tabular}

According to the Czech technical standard (ČSN 73 6102, 2007), the afore-mentioned ramp belongs to category $\mathrm{O} 1$, where the maximum capacity is set as 1,500 vehicles per hour for the $15 \%$ share of slow vehicles. The share of slow vehicles has been found to be $20.5 \%$ on the above mentioned ramp. Such a value reduces the capacity by $5.25 \%$, according to the standard, so resulting in a value of 1,421 vehicles per hour. Detailed information can be found in TP 236 (Rozsypal, 2011), Chapter 4.2.

German guidelines (HBS, 2001) indicate the same value as the Czech standards (ČSN 73 6102, 2007), i.e. 1,500 vehicles per hour. This value remains for proportions 
of heavy good vehicles up to $20 \%$. For higher proportions the value of the maximum capacity is reduced to 1,350 vehicles per hour, which corresponds with the proportion of heavy vehicles of $20.5 \%$. It is evident that a reduction of the heavy vehicles proportion of just $0.5 \%$ calculated in accordance with the German methodology represents an enormous impact on the capacity assessment. Such a big reduction from 1,500 to 1,350 vehicles per hour seems to be rather disproportional and may, in the course of assessment, require a lot of the traffic engineer's experience.

Examination according to the HCM guidelines (HCM, 2000) enables the taking into account of the speed of the traffic flow. The average speed of free traffic flow was found to be lower than $50 \mathrm{~km} / \mathrm{h}$ in our study. This value corresponds with the capacity of 1,900 pce/h ("Passenger Car Equivalent" vehicles). The earlier mentioned ramp goes up-hill (3\%) by a length of 500 meters, so the coefficient 1.5 can be used for the conversion of heavy, long vehicles and buses into unitary vehicles. The value of the ultimate capacity measured, after correction, is $1,657 \mathrm{pce} / \mathrm{h}$. Theoretical assumption used in the US guidelines is $15 \%$ higher than the measured value.

It can be concluded that the value of ultimate capacity, found by the traffic survey, is higher than the theoretical value listed in the Czech technical standard (ČSN 73 6102, 2007) and the German guidelines (HBS, 2001). On the contrary, the value of theoretical capacity stated in the US guidelines is expressly higher than afore-measured value.

Measurement was carried out at a single station. It would be appropriate to carry out surveys on more ramps with different parameters on multiple measurements, however the project did not have enough money.

\section{COMPARISON OF ALL MEASURED TRAFFIC VOLUMES WITH THEORETICAL VALUES STATED IN RELEVANT METHODOLOGIES AND GUIDELINES}

The comparison is depicted by the vertical lines shown in Figure 7. These lines indicate the ultimate values according to the Czech technical standard ČSN 736102 (2007) and the German HBS (HBS, 2001).

According to the German HBS (HBS, 2001), the ultimate value of 1,500 vehicles per hour remains for up to $20 \%$ of the share of slow vehicles. This corresponds with the red and especially the blue dots in the graph in Figure 7. With a higher share of slow vehicles the capacity is 1,350 vehicles per hour; this corresponds especially with the yellow and green dots in the graph in Figure 7. While the basic value of capacity (1,500 vehicles per hour) seems to be set relatively realistically in the HBS guidelines (HBS, 2001), the values measured in our project indicate that even intervals with more than a $25 \%$ share of slow vehicles surpassed the value of 1,350 vehicles per hour (green line).

According to the Czech technical standard (ČSN 73 6102, 2007) the highest value of capacity (1,500 vehicles per hour) corresponds with $15 \%$ of slow vehicles. A $20 \%$ share of slow vehicles (compare with the blue dots in the graph) corresponds with a capacity of 1,425 vehicles per hour, while the share of slow vehicles (green dots) of $30 \%$ with a value of 1,350 vehicles per hour.

It is evident that the ultimate values stated in Czech technical standards (ČSN 73 6102, 2007) for different shares of slow vehicles correspond to a larger extent with values measured during our project than with values of capacity reduced according to the German HBS (HBS, 2001). 


\section{CONCLUSION}

The capacity of 1,503 vehicles per hour was found on a grade-separated junction one-lane ramp by the traffic survey, the share of slow vehicles was $20.5 \%$.

A comparison with relevant methodologies has shown a relatively good compliance with the values of the theoretical capacity stated in the Czech technical standard ČSN 736102 (2007) and the German guidelines HBS (HBS, 2001). Minimal compliance has been found with values stated in the US guidelines HCM (HCM, 2000). The value $1800 \mathrm{pc} / \mathrm{h}$ was used with the resulting methodology - TP 236 (Rozsypal, 2011).

This article is included in the dissemination activities within the research project TA01031064 Methodology Traffic Engineering Procedures for Assessing Roads supported by the Technology Agency of the Czech Republic. More information regarding the project can be found on www.edip.cz.

\section{REFERENCES}

Bartoš, L., Rozsypal, V., Kašpar, J., 2008. Kapacita větvě mimoúrovňové křižovatky Pražský okruh x K Barrandovu. Dopravní inženýrství, (1), pp. 2-4. ISSN 1801-8890. (in Czech)

ČSN 73 6102, 2007. Projektování křižovatek na pozemních komunikacích, změna Z1, 2009. (in Czech)

FGSV, 2008. Richtlinien für die Anlage von Autobahnen. Köln: FGSV. ISBN 978-3-93971551-1.

HBS, 2001. Handbuch für die Bemessung von Strassenverkehrsanlagen (HBS). Köln: FGSV. Fassung 2009. ISBN 3-937356-44-4.

HCM, 2000. Highway Capacity Manual (HCM). Washington, D.C.: National Research Council. ISBN 0-309-06681-6.

Martolos, J., 2012. TP 189 Stanovení intenzit dopravy na pozemních komunikacích, 2. vydání. Plzeň: EDIP s.r.o. ISBN 978-80-87394-06-9. (in Czech)

Rozsypal, V., 2007. Projekt č. CG723-032-910 „Aktualizace výpočtových modeli̊ pro stanoveni kapacity mimoúrovňových křžovatek". [Redakčně upravená závěrečná zpráva 2007]. Plzeň: EDIP s.r.o. (in Czech)

Rozsypal, V., 2011. TP 236 Posuzování kapacity mimoúrovňových křižovatek [Assessment of capacity grade separated junctions]. Plzeň: EDIP s.r.o. ISBN 978-80-87394-04-5. (in Czech) 